\title{
Measurement of rheumatoid factors by an enzyme-linked immunosorbent assay (ELISA) and comparison with other methods
}

\author{
J L M BAMPTON, T E CAWSTON, M V KYLE, AND B L HAZLEMAN \\ From the Rheumatology Research Unit, Addenbrooke's Hospital, Hills Road, Cambridge CB2 $2 Q Q$
}

SUMMARY IgM rheumatoid factor (RF) was measured in the sera of 48 rheumatoid patients and of 48 age and sex-matched normal controls by the Rose-Waaler and latex agglutination tests, a rate nephelometer, and an enzyme-linked immunosorbent assay (ELISA). Good correlation was obtained between all assays. The rate nephelometer assay was the easiest and quickest to perform and gave results in international units $/ \mathrm{ml}$. The Rose-Waaler was the least sensitive assay and the most difficult to perform and interpret. Both the latex agglutination and the ELISA were sensitive, though some overlap of patient and control sera was seen with all the assays. In addition to IgM RF the ELISA was used to measure IgG RF and IgA RF in both rheumatoid and control sera. Although some normal sera had detectable amounts of IgG and IgA RF, the levels of both were significantly raised in the rheumatoid sera. IgG RF levels were lower after pepsin digestion of the sera, suggesting that IgM RF interfered with the assay for IgG RF unless this treatment was included.

Key words: arthritis rheumatoid, Rose-Waaler test, latex fixation test, nephelometry.

Rheumatoid factors (RF) are anti-IgG autoantibodies with specificity directed against antigenic determinants in the Fc region of IgG. ${ }^{1}$ They are present in the large majority of patients with rheumatoid arthritis and have long been found to be associated with the more severe forms of rheumatoid disease. The measurement of RFs is important in the diagnosis of rheumatoid arthritis and in determining prognosis, especially in high titres, as these patients tend to develop extra-articular complications. In addition it has been proposed that RFs are important in the pathogenesis of the disease. ${ }^{2}$ There is considerable evidence that RF contributes extensively to the immunopathology of RA, as it is the predominant antibody known to initiate immune complex formation and complement activation in the peripheral circulation and in tissue sites. ${ }^{2} 3$

The majority of routine laboratory tests for the detection of rheumatoid factor measure IgM RF by its ability to agglutinate sheep red blood cells, latex, or similar particles coated with IgG. ${ }^{4-6}$ However, recent publications have suggested that both IgG

Accepted for publication 18 July 1984.

Correspondence to Dr J L M Bampton.
$\mathrm{RF}^{2}{ }^{7}$ and IgA RF are also raised in seropositive RA, and IgG RF may be associated with the more severe extra-articular complications of the disease such as vasculitis. ${ }^{38}$

The majority of hospital laboratories still routinely measure IgM RF by either the RoseWaaler or latex agglutination test. These methods are both difficult to quantitate, and we have found that there is a large variation in titres for the same sera between different laboratories. In addition it is not possible to measure either IgG RF or IgA RF by these methods. Although procedures have been described for the measurement of different classes of RF, specialised reagents and equipment are generally required. More recently suitable ELISA methods have been reported which can be routinely used in clinical laboratories. ${ }^{9} 10$

In this study we have compared four methods for the estimation of IgM RF and developed an ELISA method that can also measure IgG RF and IgA RF.

\section{Materials and methods}

All reagents were of analytical grade and were 
obtained from Sigma Ltd, Poole, UK, unless otherwise indicated.

Patients and controls. Sera were obtained from 48 rheumatoid patients with active disease attending routine rheumatology outpatient clinics and from 48 age and sex matched normal healthy blood donors. All sera were stored at $-70^{\circ} \mathrm{C}$, thawed before use and heated at $56^{\circ} \mathrm{C}$ for $30 \mathrm{~min}$ before use to inactivate complement.

Development of ELISA. Rabbit IgG (R IgG) and human Fc were both tested as antigen in an ELISA. No significant difference was found between them, and $\mathrm{R} \mathrm{IgG}$ was used in all further tests.

Evaluation of microtitre plates. Microtitre plates were obtained from four manufacturers: Nunc (Gibco Ltd, Paisley, Scotland), Falcon (Becton Dickinson UK Ltd, Cowley, Oxford), Linbro (Flow Laboratories Ltd, Irvine, Ayrshire, Scotland), and Dynatech (Dynatech Laboratories, Billinghurst, Surrey) and tested by measuring the amount of ${ }^{125}$ I-labelled R IgG bound to each well. Although Falcon plates bound slightly greater amounts of IgG than Linbro or Dynatech, no significant difference in final sensitivity was found, and the lower-cost Linbro plates were subsequently used. No significant difference was found between the amount of $R$ IgG bound by wells at the centre and wells at the edge of any plate.

Binding of $R \lg G$ to microtitre plates. The amount of ${ }^{125}$ I-labelled R IgG bound to microtitre plates was estimated under different conditions of time (2-24 h), temperature $\left(4^{\circ} \mathrm{C}, 22^{\circ} \mathrm{C}, 37^{\circ} \mathrm{C}\right), \mathrm{pH}(2 \cdot 0,7 \cdot 2$, $9 \cdot 6)$, and concentration $(10-500 \mu \mathrm{g} / \mathrm{ml})$. The optimum conditions chosen for binding of $\mathrm{R}$ IgG were an overnight treatment at $37^{\circ} \mathrm{C}$ of $50 \mu \mathrm{l}$ of a $100 \mu \mathrm{g} / \mathrm{ml}$ solution in $50 \mathrm{mM}$ sodium carbonate buffer $\mathrm{pH} 9 \cdot 6$.

Blocking of non-specific antibody adsorption after IgG coating. No significant difference in titre was found between wells treated with bovine serum albumin $(100 \mu \mathrm{g} / \mathrm{ml})$ in either phosphate buffered saline (PBS) or sodium carbonate buffer ( $\mathrm{pH} \mathrm{9.6)}$ for 1 hour at $37^{\circ} \mathrm{C}$ after $\mathrm{R} \mathrm{IgG}$ adsorption and wells when this treatment was omitted.

Investigation of temperature and time of incubation. Various incubation times and temperatures were investigated for each stage of the ELISA assay. The optimum conditions chosen for a one-day assay were incubation of the plate with serum for $3 \mathrm{~h}$ at $4^{\circ} \mathrm{C}$; incubation with enzyme conjugate for $2 \mathrm{~h}$ at $4^{\circ} \mathrm{C}$, and incubation with enzyme substrate for 30 min at $37^{\circ} \mathrm{C}$.

Investigation of enzyme substrate. The substrates $o$-phenylenediamine (OPD) and 2,2'-azino-di(3ethyl-benzthiazoline-6-sulphonic acid) for peroxidase and $p$-nitrophenyl phosphate for alkaline phosphatase were investigated. The most sensitive substrate was $\mathrm{OPD}$, and so horseradish peroxidas immunoglobulin conjugates were subsequentl used.

Final ELISA protocol. R IgG $(50 \mu \mathrm{l})$ at concentration of $100 \mu \mathrm{g} / \mathrm{ml}$ in $50 \mathrm{mM}$ sodiur carbonate buffer $\mathrm{pH} 9.6$ was added to Linbro E1 microtitre plates. Wells containing sodium carbon ate buffer $(50 \mu \mathrm{l})$ only were prepared as controls The plates were sealed with Nescofilm (Jencons Scit Ltd, Leighton Buzzard, UK), incubated overnighit at $37^{\circ} \mathrm{C}$, then washed three times with PBS $+0.05 \%$ Tween 20 (PBST), soaking for $3 \mathrm{~min}$ between eaco wash. Serum was diluted 1:10 and in a further seve 1:4 dilutions across the plate, so that each serum was tested in a dilution range of 1:10 to 1:138 240 . Aliquots $(50 \mu \mathrm{l})$ of each dilution were added to tesit and control wells. The plates were incubated fow 3 hours at $4^{\circ} \mathrm{C}$ and then washed three times as previously described. The peroxidase-conjugated second antibody was diluted $1: 1000$ in PBST Aliquots $(50 \mu \mathrm{l})$ were added to each well and the plates incubated at $4^{\circ} \mathrm{C}$ for $2 \mathrm{~h}$. OPD $(20 \mathrm{mg})$ was prepared immediately before use in citric-phosphat $\overrightarrow{0}$ buffer $\mathrm{pH} 5 \cdot 0(20 \mathrm{ml})$ and then $\mathrm{H}_{2} \mathrm{O}_{2}(8 \mu \mathrm{l}$ of $30 \%$ solution) was added. Aliquots $(50 \mu \mathrm{l})$ of OPD in buffer were added to each well and the plates incubated in the dark at $37^{\circ} \mathrm{C}$ for $30 \mathrm{~min}$. The reaction was stopped by the addition of $2 \mathrm{M} \mathrm{H}_{2} \mathrm{SO}$ $(50 \mu l)$ to all wells and the absorbance of each we ph read at $492 \mathrm{~nm}$ with a Titertek multiscan (Flow Laboratories, Irvine, UK). The results were ex? pressed as $\log _{10}$ titre at an absorbance value of 0.4

Measurement of RF immunoglobulin class. IgN $\mathrm{RF}$ and IgA RF were detected with peroxidase conjugated rabbit antihuman $\mu$ chain and antihuma $\alpha$ chain immunoglobulins (Dako, Mercia Brocadè Ltd, Weybridge, UK). IgG RF was detected b尹 means of a rabbit antihuman IgG/Fab antibod (Nordic Immunological Labs Ltd, Maidenhead Berks), which was conjugated to horseradish peroxe idase by the method of Wilson and Nakane 1978. $\stackrel{1 P}{>}$

Treatment of sera with dithiothreitol and pepsine Sera were reduced with an equal volume of $10 \mathrm{~mm}$ dithiothreitol in PBS at $37^{\circ} \mathrm{C}$ for $1 \mathrm{~h}^{12}$ and the F $^{1}$ assayed by the procedure outlined above.

Sera were pepsin digested by a modification of the्心 method of Faith et al. ${ }^{10}$ The concentration of pepsit chosen was that which destroyed all IgM RF as detected by our ELISA. Sera were diluted 1:20 if pepsin-acetate buffer $150 \mu \mathrm{g} / \mathrm{ml}$ pepsin in $100 \mathrm{mK}$ acetate buffer ( $\mathrm{pH} \mathrm{4.4)} \mathrm{incubated} \mathrm{for} 20 \mathrm{~h}$ at $37^{\circ} \dot{\mathrm{G}}$ and then neutralised with an equal volume of 0.56. $M$ disodium hydrogen phosphate in PBST. Contro sera were incubated in $100 \mathrm{mM}$ acetate buffer pl 4.4 for $20 \mathrm{~h}$ at $37^{\circ} \mathrm{C}$ and then neutralised as above The sera were then assayed by the ELISA with the 
lowest dilution being 1:40. IgG RF and IgM RF levels were measured in sera before and after reduction with DTT and before and after pepsin digestion.

\section{OTHER RF ASSAYS}

Rose-Waaler test. The sera were adsorbed by adding $0.1 \mathrm{ml}$ of concentrated washed sheep red blood cells (SRBC) to $0.5 \mathrm{ml}$ of serum and incubated at $4^{\circ} \mathrm{C}$ overnight. Sensitised SRBC were prepared by adding a $2 \%(\mathrm{v} / \mathrm{v})$ solution of washed SRBC in saline to an equal volume of rabbit antisheep cell serum (Wellcome Reagents Ltd, Beckenham, England) at its sensitising dilution. The inactivated adsorbed sera were titrated against the sensitised cells in microtitre plates: $40 \mu \mathrm{l}$ of saline was added to all wells. $40 \mu \mathrm{l}$ of inactivated adsorbed serum was added to the first well, mixed, and $40 \mu \mathrm{l}$ transferred to the next well. In this way the serum was diluted across the plate. $40 \mu \mathrm{l}$ of sensitised cells was then added to each well, and the plates incubated at $37^{\circ} \mathrm{C}$ for $1.5 \mathrm{~h}$. Cells which had settled into a completely negative button were reported as negative, and those sera with a titre of $<1: 16$ were considered negative.

Latex agglutination. The test was carried out with the Mercia Brocades latex kit (Mercia Brocades, Weybridge, UK). Titres of $<1: 20$ were considered negative.

Rate nephelometry. A rate nephelometric assay for RF was performed with the Beckman Immunochemistry System (Beckman R11C, High Wycombe, UK). The nephelometer measures the changes in light scatter when serum containing IgM $\mathrm{RF}$ is added to partially aggregated human IgG. The rate of formation of the complexes is estimated by reference to a precalibrated standard curve, and the value is displayed as international units $/ \mathrm{ml}$. Levels of $<60 \mathrm{IU} / \mathrm{ml}$ were considered negative.

The Beckman ICS was also used to measure IgG, $\operatorname{IgA}$, and $\operatorname{IgM}$ levels in all sera and results were expressed as $\mathrm{mg} / 100 \mathrm{ml}$.

Statistical analysis. The results from the four assays were analysed by the Mann-Whitney $U$ test and the effect of pepsin and DTT on IgG RF levels analysed by the Wilcoxon rank sum test. Correlations were determined by calculating Spearman's rank correlation coefficient.

\section{Results}

COMPARISON OF ASSAYS FOR IgM RF

The IgM RF levels of both normal and pathological sera as measured by each assay are shown in Fig. 1a. The results are shown as $\log _{10}$ titre for the RoseWaaler, latex agglutination, and ELISA assays and $\log _{10} \mathrm{IU} / \mathrm{ml}$ for the nephelometer. The levels of IgM $\mathrm{RF}$ were significantly raised $(\mathrm{p}<0.0001)$ in $\mathrm{RA}$ patients' sera compared with normal sera in all assays. IgM RF levels correlated well between all assays as shown in Table 1 . The strongest correlation was found between the latex agglutination assay and the ELISA, though all correlations were $\geqslant 0.7000$ and were significant at $p<0 \cdot 0001$.

Results were considered negative if the titre was $<1: 16$ (Rose-Waaler test) or $<1: 20$ (latex agglutination test). All normal samples were negative for these two tests, while $60 \%$ of RA patients' sera had a titre of $\geqslant 1: 16$ in the Rose-Waaler test and $90 \%$ of RA patients had a titre of $\geqslant 1: 20$ in the latex agglutination test. A value of $60 \mathrm{IU} / \mathrm{ml}$ was considered to be negative in the nephelometer method, and $98 \%$ of the normal sera were below this level; $69 \%$ of the RA patients had values above this figure. A value of $1.75\left(\log _{10}\right.$ titre) was chosen for the IgM RF ELISA, which corresponded to the mean +2SD of the normal sera. With this figure $92 \%$ of RA patients had elevated levels of RF while $94 \%$ of the normal persons were negative.

\section{MEASUREMENT OF IgA RF AND IgG RF}

Different immunoglobulin classes of RF were detected with the ELISA protocol, and second antibody-enzyme conjugates specific for $\operatorname{IgG}$ and $\operatorname{IgA}$ were used.

The levels of IgA RF in patients' serum was measured by a rabbit antihuman $\alpha$ chain-peroxidase conjugate. The levels of IgA RF in RA patients' serum were significantly raised $(\mathrm{p}<0.000 \mathrm{I})$ relative to those in normal sera (Fig. 1b) and $88 \%$ were above the mean +2 standard deviations of normal sera $\left(1.211 \log _{10}\right.$ titre). The majority $(94 \%)$ of normal sera were below this level. The levels of IgG RF measured in RA patients and control sera with a rabbit antihuman IgG/Fab antibody-peroxidase complex are also shown in Fig. 1b. The levels of IgG RF were significantly raised $(p<0.0001)$ in RA patients relative to normal sera. However, although the majority of RA patients sera $(85 \%)$ were above the mean +2 standard deviations of normal sera (1.903), and $96 \%$ of normal sera had IgG RF levels below this value, owing to the large range of normal values there was considerable overlap with the lower pathological sera values. For a more accurate estimate of IgG RF both normal and RA patient sera were treated with pepsin. After pepsin digestion IgG RF activity in all normal sera was reduced to below a titre of $1: 40$ and was significantly reduced $(p<0.0001)$ in RA patients sera (Fig. 1c). (The method for pepsin digestion did not allow IgG. RF titres to be measured below a value of 1:40.) All values for normal sera were $<1: 40$ after pepsin 


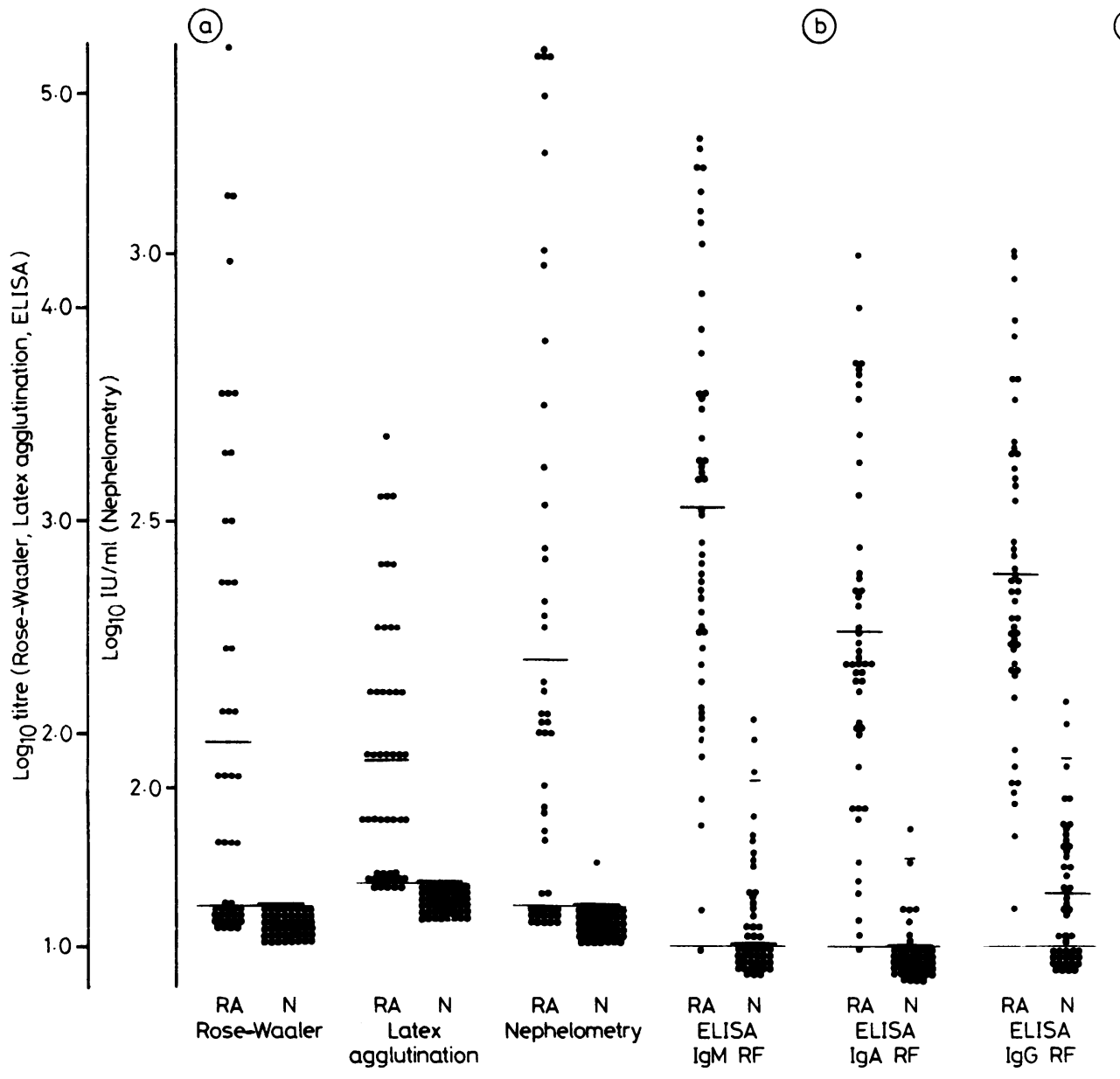

Fig. 1 Estimation of rheumatoid factor in rheumatoid control sera-comparison of assays. (a) The levels of IgM RF in 48 rheumatoid and 48 age and sex matched controls were measured by the Rose-Waaler, latex agglutination, rate nephelometrie assays and ELISA as described in the 'Methods' section. (b) The levels of IgA RF and IgG RF were measured in rheumatoi更 and control sera by the ELISA. (c) The level of IgG RF was measured in rheumatoid and control sera after pepsin digestion? This treatment destroys $\operatorname{IgM} R F$, which can interfere with the measurement of $\operatorname{Ig} G R F$. The horizontal bars indicate the mean values for each group.

Table 1 Correlation coefficients of the levels of $\operatorname{IgM} R F$ between assays

\begin{tabular}{|c|c|c|c|}
\hline & Latex agglutination & Nephelometry & $E L I S A$ \\
\hline Rose-Waaler & $0 \cdot 8178$ & 0.6998 & $0 \cdot 8029$ \\
\hline Latex agglutination & - & 0.7635 & 0.8733 \\
\hline Nephelometry & - & - & $0 \cdot 8121$ \\
\hline
\end{tabular}

The correlation coefficients of the levels of IgM RF between the four assays were measured by calculating Spearman's rank correlation coefficient. All correlations were significant at $\mathrm{p}<0 \cdot 0001$. digestion, while $46 \%$ of the RA patients sera were above this value. There was a high degree correlation between all classes of RF measured bo ELISA in RA patients sera (Table 2).

The total immunoglobulin levels for both normat and RA patients' sera were measured and are show in Fig. 2. The levels of all immunoglobulins wer苗 significantly raised in RA patients' sera whe compared with the levels in normal sera (IgG anf IgM at $\mathrm{p}<0.0001$ and $\operatorname{IgA}$ at $\mathrm{p}<0.0002)$. Table 
Table 2 Correlation between RFs of different immunoglobulin class in rheumatoid patients' sera

\begin{tabular}{lll}
\hline & $\lg A R F$ & $\lg M R F$ \\
\hline IgG RF & 0.7701 & 0.9184 \\
Pepsin IgG RF & 0.7403 & 0.7224 \\
IgA RF & - & 0.7329 \\
\hline
\end{tabular}

The correlation coefficients between the levels of IgG, IgA, and IgM RFs in rheumatoid patients' sera were measured by calculating the Spearman's rank correlation coefficient. All correlations were significant at $\mathrm{p}<0 \cdot 0001$.

illustrates the correlations obtained between the different classes of RF with the total immunoglobulin content of RA patients' sera. Good correlation was found between the levels of IgG and IgA in RA patients' sera, but correlation between other immunoglobulin classes in RA and normal sera were low.

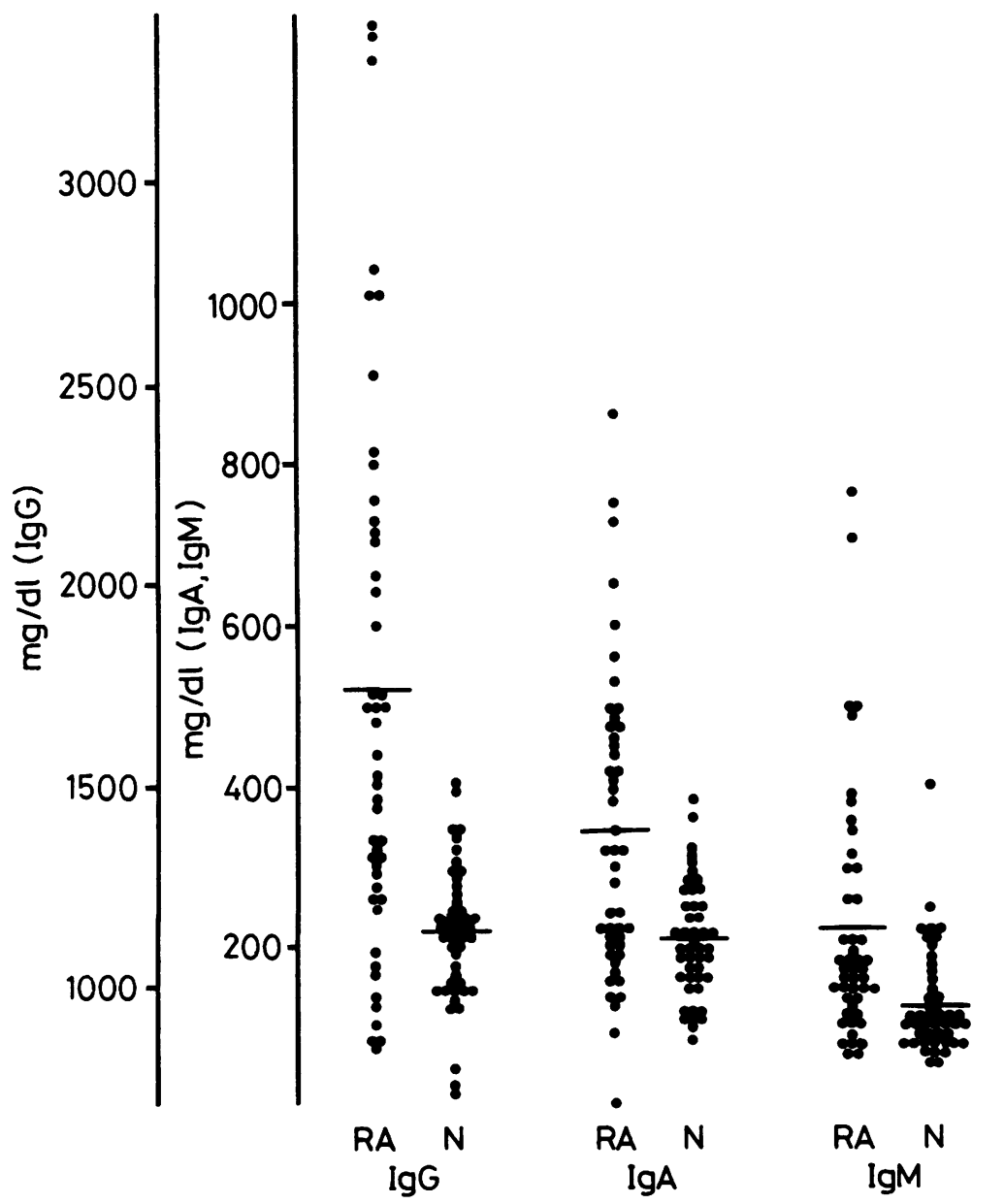

Table 3 Correlation between immunoglobulin levels in rheumatoid and normal sera

\begin{tabular}{lll}
\hline & IgA & IgM \\
\hline RA patients: & & \\
IgG & 0.6799 & 0.4111 \\
IgA & - & $0 \cdot 3442$ \\
Normals: & & \\
IgG & $0 \cdot 1880$ & 0.2798 \\
IgA & - & 0.0515 \\
\hline
\end{tabular}

The correlation coefficients between the levels of $\operatorname{IgG}, \operatorname{IgA}$, and IgM in rheumatoid and normal sera were calculated.

\section{Discussion}

At present there is considerable interest in ELISA assays in the clinical laboratory. These assays represent a quick and cost-effective way of processing large numbers of samples while using simple
Fig. 2 Total immunoglobulin levels of rheumatoid and control sera. The levels of $\operatorname{Ig} G, \operatorname{Ig} A$, and IgM in rheumatoid and control sera were measured by a nephelometric assay. The horizontal bars indicate the mean values for each group. (SI conversion: $m g / d l \times 10=m g / l$.) 
and relatively inexpensive equipment. A number of ELISA methods have been published for measuring $R F,{ }^{10}{ }^{13-15}$ but they have had a restricted routine usage, and the more common Rose-Waaler and latex agglutination assays are still performed in the majority of hospital service laboratories. If the ELISA assay is to gain general acceptance, it must be carefully compared with other methods. In the present study we have compared the two traditional methods with a rate nephelometric assay and an ELISA for rheumatoid factor. There was good correlation for IgM RF values between all assays. Although the Rose-Waaler and latex agglutination tests are relatively easy to perform, the end points of both assays are difficult to determine without experience, and both assays are prone to observer variability. Consistent results can be obtained with care in one laboratory if the same personnel repeat the test from week to week, but interlaboratory variation for the same sera is high. The rate nephelometric assay was the easiest and quickest test to perform and gave quantitative results in a very short time. It is useful for following patients serially over a period of time, and consistent results are obtained from serum samples when assayed at different times. Of the four assays tested the rate nephelometric assay gave the most consistent results. Other assays had to be run with a standard and the titres adjusted up or down for all samples according to the result obtained for the standard. The ELISA was quick and easy to perform and would suit a routine laboratory. It was the most sensitive assay and recognised $92 \%$ of rheumatoid patients' sera as positive. The corresponding figures for the other assays were latex agglutination test $90 \%$, rate nephelometric assay $69 \%$, and RoseWaaler $60 \%$.

The ELISA was also able to measure $\operatorname{IgG}$ and $\operatorname{IgA}$ $R F$ in addition to IgM RF. The results were quoted in titres for the ELISA, but it can be adapted by incorporating a standard curve to give quantitative results in $\mu \mathrm{g} I \mathrm{gM} \mathrm{RF} / \mathrm{ml}^{10}$ or in international units. ${ }^{13} 15$ We are currently evaluating quantitation of the assay using these methods and interfacing the ELISA reader to a computer to automate the estimations and allow the results to be calculated by reference to a standard curve.

The classical tests for RF usually meấsure only IgM RF, but in recent years increasing attention has focused on the role of both $\operatorname{IgG}$ and $\operatorname{IgA}$ RF. IgG RF was first measured quantitatively by Torrigiani and Roitt. ${ }^{16}$ Since that time many different assay protocols for the measurement of IgG RF and IgA RF have been published, and the most widely used are radioimmunoassay, ${ }^{2}>817-19$ immunofluorescent techniques, ${ }^{2021}$ or ELISA. ${ }^{101314}$ March et al. ${ }^{22}$ have published a simple microtitre plate assay using immunoglobulin coupled to red blood cells.

The significance of the raised levels of IgG RF inf rheumatoid disease is not clear. Early reports suggested that $\operatorname{IgG} \mathrm{RF}$ was significantly raisec in both seropositive and seronegative arthritides. ${ }^{1623-25}$ However, it is now thought that these early results were incorrect, and subsequent studies using more sensitive and specific methods of detec $-\overrightarrow{0}$ tion have shown that significant levels of IgG RF are not associated with seronegative diseases. ${ }^{1} 217$ IgM RF can interfere with the measurement of IgG RF int solid phase assays, as it can bind to the immobilise $\overline{5}$ target IgG and to IgG in the serum. The bound serum IgG is then detected with the antibody.conjugate as IgG RF. Two methods have been use $\oint_{0}$ to destroy IgM in the test serum and so prevent these interactions. These are either pepsin digestion $^{101726}$ or treatment with a reducing agent. ${ }^{721}$ In this study we used pepsin digestion and adapted the method of Faith et al. ${ }^{10}$ to adjust the level of pepsin so that all serum IgM was destroyed. We found that the results obtained after reductiono and alkylation of sera were variable and that highefr levels of IgG RF were present in control sera aftero this treatment. Similar findings have been reported by Carson et al. ${ }^{7}$ and Wernick et al. ${ }^{17}$ and so pepsin digestion was considered to be the method of choice.

High titres of IgG $R \bar{F}$ are associated with the more severe forms of rheumatoid disease, anf patients with vasculitis or subcutaneous noduleshave high levels of serum IgG RF. ${ }^{3825}$ Immune complexes containing IgG RF have been detected iñ the serum, synovial fluid, and synovium of patients with rheumatoid arthritis, ${ }^{2}$ and the levels of IgG RFare higher in synovial fluid than in the correspond? ing serum sample. ${ }^{25}$ This suggests that locally produced IgG RF may be important in the pathogenesis of the disease maintaining the rheumas toid synovitis through its ability to activate comple $\rightarrow$ ment by self-associating ${ }^{27}$ or in combination witle IgM RF. The vasculitic lesions probably result from the deposition of pathogenic immune complexes if the microvasculature of the skin and other targef organs, and IgG RF appears to be present in mantw of these complexes. ${ }^{20}$ In addition it is possible thap IgG RF may aggregate platelets in vivo and s@ promote vascular damage. ${ }^{8}$

Relatively little interest has been shown in the finding that the levels of $\operatorname{IgA} \mathrm{RF}$ are raisedo in rheumatoid patients, though this finding has been previously reported. ${ }^{21-23} 2829$ Dunne $e \$$ $a{ }^{28}$ demonstrated that IgA RF was present in no $\vec{B}$ only the serum but also the saliva of rheumatoids patients and patients with Sjögren's syndrome. The् 
IgA RF showed a pattern of reaction with human IgG subclasses similar to that of IgM RF from the same patients. Koopman et al. ${ }^{29}$ detected significantly raised levels of IgA RF in rheumatoid sera and synovial fluid compared with serum from patients with seronegative disease or normal control serum. In the present study we obtained similar results, finding significantly raised levels of IgA RF in rheumatoid sera, but their significance in the immunopathogenesis of the disease is unknown.

Rheumatoid factor measurement by the conventional tests of Rose-Waaler and latex agglutination are difficult to quantify. We found that the nephelometric assay is rapid, reproducible, and allows results to be presented as international units $/ \mathrm{ml}$. The ELISA for rheumatoid factor is simple to perform and interpret and uses equipment which is present in the majority of routine hospital laboratories. We aim to develop a screening test to distinguish quickly between positive and negative sera and also use a standard curve in each assay so that results are quoted in either international units $/ \mathrm{ml}$ or $\mu \mathrm{g} \mathrm{RF} / \mathrm{ml}$.

We thank Ms Sarah Roberts (Department of Community Medicine, University of Cambridge) for advice and help with the statistical analysis and Mrs Jane McAusland for typing the manuscript. This work was generously supported by the Arthritis and Rheumatism Council and the East Anglian Regional Health Authority.

\section{References}

1 Johnson P M, Faulk W P. Rheumatoid factor: its nature, specificity and production in rheumatoid arthritis. Clin Immunol Immunopathol 1976; 6: 414.

2 Pope R M, McDuffy S. IgG rheumatoid factor. Relationship to sero-positive rheumatoid arthritis and the absence in seronegative disorders. Arthritis Rheum 1979; 22: 988-98.

3 Scott D G I, Bacon P A, Allen C. Elson C J, Wallington T. IgG rheumatoid factor, complement and immune complexes in rheumatoid synovitis and vasculitis: comparative and serial studies during cytotoxic therapy. Clin Exp Immunol 1981; 43: 54-63.

4 Waaler $E$. On the occurrence of a factor in human serum activating the specific agglutination of sheep blood corpuscles. Acta Pathol Microbiol Scand 1940; 17: 172.

5 Rose H M, Ragan C, Pearce E, Lipman M O. Differential agglutination of normal and sensitised sheep erythrocytes by sera of patients with rheumatoid arthritis. Proc Soc Exp Biol Med 1948; 68: 1-6.

6 Singer J M, Plotz C M. The latex fixation test. Am J Med 1956; 21: $888-92$

7 Carson D A, Lawrance S, Cataland M A, Vaughan J H, Abraham G. Radioimmunoassay of IgG. IgM rheumatoid factors reacting with human IgG. J Immunol 1977; 119: 295-300.

8 Allen C, Elson C J, Scott D G I, Bacon P A, Bucknall R C. IgG antiglobulins in rheumatoid arthritis and other arthritides: relationship with clinical features and other parameters. Ann Rheum Dis 1981; 40: 127--31.
9 Nishimaki I, Watenabe S. Yoshida H. Kasukawa R. Immunoglobulin class of rheumatoid factors detected by enzyme-linked immunosorbent assay. Clin Rheumatol 1983; 2: 145-51.

10 Faith A, Pontesillia G, Unger A, Panayi G S, Johns P. ELISA assays for IgM and IgG rheumatoid factors. $J$ Immunol Meth 1982: 55: 167-77.

11 Wilson W B. Nakane P K. Immunofluorescence and related techniques. In: Knapp W. Holnbark, Wick G. Amsterdam: Elsevier Holland, 1978: 215.

12 Palosuo T. Milgram F. IgG RF detection by EIA in RA and normal subjects. J Immunol Meth 1981; 41: 171-81.

13 Karsh J, Halbert S P, Klima E, Steinberg A D. Quantitative determination of rheumatoid factor by an enzyme-linked immunosorbent assay. J Immunol Meth 1980; 32: 115-26.

14 Vejtorp M, Hoier-madsen M, Halberg P. Enzyme-linked immunosorbent assay for determination of IgM rheumatoid factor. Scand J Rheumatol 1979; 8: 59-63.

15 Zoila B, Tuokko H. Solid-phase enzyme immunoassay of IgM-class rheumatoid factor. Acta Pathol Microbiol Scand Sect C 1980: 88: $127-30$.

16 Torrigiani G. Roitt I M. Antiglobulin factors in sera from patients with rheumatoid arthritis and normal subjects $A n n$ Rheum Dis 1967; 26: 334-40.

17 Wernick R, Lospalluto J J. Fink C W. Ziff M. Serum IgG and IgM rheumatoid factors by solid-phase radio-immunoassay. Arthritis Rheum 1981: 24: 1501-11

18 Nordfang D, Hoier-Madsen M, Halberg P, Licberkin J. A new radioimmunoassay for IgM and IgG rheumatoid factors based on a double antibody method. J Immunol Meth 1981; 47: 87-97.

19 Yamagata J, Barnett E V, Knutson D W. Nasu H, Chia D. Characterisation and measurement of anti-IgG antibodies in human sera by radioimmunoassay. J Immunol Meth 1979; 29: 43-56.

20 Quismorio F P. Beardmore T. Kaufman R L, Mongan E S. IgG rheumatoid factors and anti-nuclear antibodies in rheumatoid vasculitis. Clin Exp Immunol 1983; 52: 333-40.

21 Kallerup H E. Egeskjold E M, Graudel H. IgG, IgM and IgA rheumatoid factors in healthy adults and rheumatoid patients determined by an indirect immunofluorescence method. Scand J Rheumatol 1979; 8: 1-9.

22 March R E, Reeback J S, Holborow E J, Coombs R R A. Mrs $\mathrm{P} \mathrm{A} \mathrm{H}$, a simple microtitre plate test for rheumatoid factors of different classes. J Immunol Meth 1981; 42: 137-46.

23 Torrigiani G, Ansell B M. Chown E E A. Roitt I M. Raised IgG antiglobulin factors in Still's disease. Ann Rheum Dis 1969; 28: 424-7.

24 Howell F A, Chamberlain M A. Perry R A. Torrigiani G, Roitt I M. IgG antiglobulin levels in patients with psoriatic arthropathy, ankylosing spondylitis and gout. Ann Rheum Dis 1972; 31: $129-31$.

25 Hay C, Neneham L J. Percival R. Roitt I M. Intra-articular and circulating immune complexes and antiglobulins (IgG and IgM) in rheumatoid arthritis, correlation with clinical features. Ann Rheum Dis 1979; 38: 1-7.

26 Theofilopoulos A N, Burtonboy G. Lospalluto J J. Ziff M. IgM rheumatoid factor and low molecular weight IgM. An association with vasculitis. Arthritis Rheum 1974: 17: 272-84.

27 Pope R M. Mannik M. Gilliland B C. Teller D C. The hyperviscosity syndrome in rheumatoid arthritis due to intermediate complexes formed by the self-association of $\operatorname{lgG}$ rheumatoid factors. Arthritis Rheum 1975; 18: 97-106.

28 Dunne J V, Carson D A. Spicgelherg H L, Alspaugh M A. Vaughan $\mathrm{J} \mathbf{H}$. IgA rheumatoid factor in the sera and saliva of patients with rheumatoid arthritis and Sjögren's syndrome. Ann Rheum Dis 1979; 38: 161-5.

29 Koopman W J. Schrohenloher R E. Solomon A. A quantitative assay for IgA rhcumatoid factor. J Immunol Methods 1982; 50: 89-98. 